\title{
The income and consumption profiles of public-sector employees: Indications of unreported income
}

\author{
A.L. Tobing \& A. Kuncoro \\ Department of Economics, Faculty of Economics and Business, Universitas Indonesia, Depok, Indonesia
}

\begin{abstract}
This study uses data from the Indonesian Family Life Survey (IFLS) to see whether there are differences between the wages of observably comparable public and private sector employees. This study also displays indications of unreported income among public-sector employees. This is shown by using private-sector employees as a control group and comparing the consumption profiles of both types of employees; we find that public employees consume more of their reported income than a comparable private employee. Finally, this paper reports that households with at least one public employee are more prone to report consumption levels above their income levels compared to households without public employees, thereby strengthening the case that public employees receive more income than they report.
\end{abstract}

\section{INTRODUCTION}

As of 2015, a survey conducted by Transparency International showed that from all national institutions, Indonesia's civil servants and public officials were perceived to be some of the most corrupt. The respondents perceived the civil service to be cleaner only to the judiciary, elected officials, political parties, and the police but more corrupt relative to the media, NGOs (Non-Governmental Organizations), religious bodies, and the private sector. What this research attempts to see is whether this perception of illegal behaviour by public-sector employees is backed up by data that does not rely on public perception.

As it may be impossible to truly demonstrate the existence of corruption through econometric analysis, we will follow the method previously used by Pissarides and Weber (1989), Gorodnichenko and Peter (2007), Gorodnichenko et al. (2009), and Hurst et al. (2014), to explore whether public-sector employees show indications of having 'unreported income'. This research is based on the logic that if someone has received an income above what they report to data collectors, they will then use that 'extra' income for consumption, wherever that extra income may have come from. Thus, the main finding of this paper will demonstrate that public-sector employees (whom we suspect of having unreported income) do indeed consume more than an otherwise comparable control group given the same levels of reported income. The control group we have chosen are employees in the private sector.

For this method to work, we must first confirm that there are negligible levels of income shifting between family members or between income sources. Due to the fact that labour income is reported at the individual level whereas expenditure is reported at the household level, the logical framework described above will not effectively show the existence of unreported income if there is income shifting, as households who untruthfully ascribe which members get how much income (or from what source) will have reported actual total household income that may already include income from corruption. The way this paper will show that there does not seem to be an attempt at income shifting is by presenting public-private income differentials at both the individual and household levels; were the differentials to be different to each other (say, by having a different sign or of a different order of magnitude), this may indicate that income shifting has indeed systematically occurred. 
We will show that the differentials at both levels of analysis are not very different from each other, along with the finding that public employees are associated with higher income levels than observably comparable private employees. The method which we use to highlight income differentials between the two types of employee stem from a rich literature concerning income differentials (see Anton and Bustillo (2013) in Spain, Azam and Prakash (2010) in India, Bargain and Melly (2008) in France, Borjas (2002) in the USA, Hyder and Rilley (2005) in Pakistan, Melly (2005) in Germany, Mueller (1998) in Canada, Nielsen and Rosholm (2001) in Zambia). This paper will also show that a majority of the households in the data we will use report expenditure levels above their income levels and that households with at least one public employee are more likely to report expenditures above their income than households with no public employees.

The main questions that this research has attempted to answer are: (1) Is there a difference of the income levels of observably comparable public and private employees at both the individual and household levels?; (2) Does substituting a public employee for a private employee, in an otherwise observably comparable household and given the same income, become associated with higher levels of consumption?; and (3) Does substituting a public employee with a private employee in an otherwise observably comparable household become associated with a higher probability to report expenditure levels higher than income levels? This paper will not dwell too much on public-private pay differentials, as that line of research will have to focus on controlling issues concerning endogeneity and a whole host of other problems regarding compensating pay differentials, which is beyond the scope of this paper.

\section{DATA AND METHODOLOGY}

The data that this research will use is the third, fourth, and fifth waves of the Indonesian Family Life Survey (IFLS) (from Strauss et al., 2004, 2009, 2016; henceforth called the IFLS), from the years 2000, 2007, and 2014, respectively. At the individual level, this author has omitted any public or private-sector employees without at least a high school or equivalent diploma, outside the prime working age (17-65), and who does not receive a regular salary. Unfortunately, the IFLS data does not allow us to distinguish between civil servants and employees of state-owned enterprises. Although our analysis at the household level will only use households that comprise at least one individual from our individual-level analysis, there are still income earners within the household who are not part of the individual-level analysis, income earners who consist of self-employed workers, casual workers, or employees not meeting the criteria for the individual-level analysis described above.

There are two key variables with which this study will be occupied: income and consumption. The IFLS asks respondents for their last month's total salary received from their primary and secondary jobs that includes the value of all benefits that respondents receive. The income of self-employed workers is taken from the approximate value of profits they receive. Other sources of income include income from pensions and assets. The individual level analysis will only use the salary from an employee's primary job, whereas the household analysis will include all forms of income. Note that the individual level analysis does not include selfemployed workers and employees not meeting the main criteria stated above, whereas the household analysis does.

The other key variable in our analysis is consumption. The IFLS asks respondents for the approximate money value of all consumption expenditures that a household makes. These expenditures include the weekly consumption of various types of food, quarterly non-durable consumption other than food, yearly expenditures on durable goods, and any monthly ritual and tax expenditures a household may make. This research omits any consumption that was produced by the household or given from outside the household so as to capture the total of only market purchases a household may make. This research converts these values to their monthly values.

There is a total of four empirical models that we will use to answer the research problems:

$$
\ln \mathrm{w}=\delta_{1}+\mathrm{X} \delta_{2}+\mathrm{S} \delta_{3}+\varepsilon_{\delta}
$$


Model (1) above will be used to answer whether there are any differences between the pay of public and private-sector employees at the individual level. $\ln \mathrm{w}$ is the log of last month's wages, $\mathrm{X}$ is a vector of covariates comprising of a gender indicator, a region indicator (rural vs. urban), highest level of education attained (high school or equivalent, tertiary vocational school, bachelor's degree, or master's and above), experience (defined as age minus years of schooling minus six), squared experience, tenure, squared tenure, a series of indicators denoting provincial location, and $\varepsilon_{\delta}$ is an error term with a mean of zero. Model (1) above is essentially an extension of a standard Mincer earnings function taken from Gorodnichenko and Peter (2007). The parameter of primary interest here is $\delta_{3}$ which will show us whether or not there are wage differentials between the two employment sectors at the individual level.

To estimate the effects of substituting a private-sector employee for a public employee on household income, the empirical model is:

$$
\ln \mathrm{Y}=\alpha_{1}+\mathrm{X} \alpha_{2}+\mathrm{N}^{\text {private }} \alpha_{3}+\mathrm{N}^{\text {other }} \alpha_{4}+\mathrm{N}^{\mathrm{IE}} \alpha_{5}+\varepsilon_{\alpha}
$$

where $\ln \mathrm{Y}$ is the natural log of total household income, $\mathrm{N}^{\text {private }}$ is the number of privatesector wage earners (labelled as 'Private Sector' in regression result tables below), $\mathbf{N}^{\text {other }}$ is the number of other sector wage earners, and $\mathrm{N}^{\mathrm{IE}}$ is the number of income earners. $\mathrm{X}$ is a set of covariates as described in Model (1) but averaged across all private- and public-sector employees in the household, and $\varepsilon_{\alpha}$ is the residual with a mean of zero.

The target parameter for Model (2) is $\alpha_{3}$. Because we have controlled the number of wage earners and individuals working in places other than the private and public sector, $\alpha_{3}$ will identify the effect of substituting one public-sector worker with a private-sector worker upon the income of the household, with other factors held constant.

The primary interest of this study is the next model, which is expected to capture the effects of substituting a private employee for a public employee within a household upon consumption, ceteris paribus, the specification of which is given by:

$$
\ln C=\beta_{1}+Z \beta_{2}+N^{\text {private }} \beta_{3}+\mathrm{N}^{\text {other }} \beta_{4}+\mathrm{N}^{\mathrm{IE}} \beta_{5}+\ln \mathrm{Y} \beta_{6}+\varepsilon_{\beta}
$$

where $\ln \mathrm{C}$ is the natural $\log$ of a household's total consumption (or non-durable consumption), $\ln \mathrm{Y}$ is the natural $\log$ of total reported household income, and $\mathrm{Z}$ is a vector of covariates which we expect to influence consumption levels that include: the number of household members, the number of children in the household, the proportion of men between income earners, the proportion of married couples between income earners, the average years of schooling between income earners, the average age of all household members, the average age of all income earners, a region dummy (rural $=0$, urban $=1$ ), a series of dummies denoting provincial location, and $\varepsilon_{\beta}$ is the residual with a mean of zero. The parameter of interest here is $\beta_{3}$, which will show the effect of substituting a private employee for a public employee, as in Model (2).

As will later be discussed in more detail, a substantial number of households in the IFLS data report consumption have expenditures larger than their total income. To test whether households have a stronger or weaker probability of reporting expenditures larger than their incomes when a private employee is substituted for a public employee, we will estimate the following model:

$$
[\operatorname{Pr}(\mathrm{C}>\mathrm{Y})=1]=\gamma_{1}+\mathrm{V} \gamma_{2}+\mathrm{N}^{\text {private }} \gamma_{3}+\mathrm{N}^{\text {other }} \gamma_{4}+\mathrm{N}^{\mathrm{IE}} \gamma_{5}+\varepsilon_{\gamma}
$$

This empirical model will be estimated by a Linear Probability Model (LPM). The dependent variable equals one when reported expenditure is larger than reported income or equals zero when reported expenditure is smaller than reported income. The parameter of interest here is $\gamma_{3}$, the sign of which will show us whether substituting a public-sector employee with a private employee will result in a decreasing or increasing probability that a household has an expenditure larger than their income, ceteris paribus. $\mathrm{V}$ is a vector of control variable that includes the region, gender, the average age of income earners, and the log of total income; $\varepsilon_{\gamma}$ is the error term with a mean of zero. 


\section{RESULTS AND DISCUSSION}

\subsection{Descriptive statistics}

Before we discuss the main findings of our analysis, it is worth taking a look at the summary differences between employees in either sector.

As can be seen in Tables 1 and 2, public employees are generally older than private employees; they also tend to be more educated than the private sector. Although the public-sector employs less than $30 \%$ of our sample, yet roughly half of all university graduates are in the public sector, whereas the great majority of private employees in the sample are high school graduates.

Another significantly different characteristic between public and private workers is the various fringe benefits public employees enjoy. The majority of public employees receive pension benefits and health insurance from their employers, whereas only $37 \%$ percent of private employees receive health insurance and less than $16 \%$ receive pension benefits from their employer. Roughly the same proportion in either sector receive credit from their employer. Whether the greater fringe benefits received by public employees are a function of their higher labour market endowments or not is outside the scope of this study, nor whether the greater benefits serve as a substitute or a complement to their wages.

Lastly, public-sector employees have significantly longer tenure than private employees: the average public employee stays at their job more than twice as long as the average private employee. This fact is telling of the inherent differences not just between the two employers but also the kinds of people they employ. The longer tenure of government workers may be due to the fact that civil servants or employees of state-owned enterprises are relatively safer from any economic fluctuations which might otherwise adversely affect private employees; another explanation may be that the average public employee tends to be more risk-averse than the average private employee, so they tend to adhere to their jobs longer than their private counterparts; or it may also be due to the relatively greater observable and unobservable amenities that public employees receive, which makes staying at their current posts more desirable.

Table 1. Summary statistics of continuous variables, by sector.

\begin{tabular}{|c|c|c|c|c|c|c|}
\hline \multirow[b]{2}{*}{ Variables } & \multicolumn{3}{|c|}{ Public sector } & \multicolumn{3}{|c|}{ Private sector } \\
\hline & $\mathrm{N}$ & Mean & $\begin{array}{l}\text { Standard } \\
\text { deviation }\end{array}$ & $\mathrm{N}$ & Mean & $\begin{array}{l}\text { Standard } \\
\text { deviation }\end{array}$ \\
\hline Age & 2,623 & 39.17 & 9.563 & 6,469 & 31.07 & 8.315 \\
\hline Years of Schooling & 2,618 & 14.32 & 2.019 & 6,452 & 13.04 & 1.748 \\
\hline Tenure & 2,623 & 12.08 & 9.111 & 6,469 & 5.303 & 5.829 \\
\hline
\end{tabular}

Table 2. Summary statistics of categorical variables, by sector.

\begin{tabular}{llllll}
\hline & \multicolumn{2}{l}{ Public sector } & & \multicolumn{2}{l}{ Private sector } \\
\cline { 2 - 3 } \cline { 5 - 6 } Variables & $\mathrm{N}$ & Proportion & & $\mathrm{N}$ & Proportion \\
\hline Employer Pension & 1,832 & 0.651 & & 5,050 & 0.151 \\
Health Insurance & 2,622 & 0.682 & & 6,468 & 0.368 \\
Employer Credit & 2,623 & 0.417 & & 6,469 & 0.418 \\
Senior High School & 2,623 & 0.405 & & 6,469 & 0.728 \\
Bachelor's Degree & 2,623 & 0.504 & & 6,469 & 0.23 \\
Female & 2,623 & 0.408 & & 6,469 & 0.366 \\
\hline
\end{tabular}

Note: Employer pension data is only available for 2007 and 2014. 


\subsection{Individual and household income regression results}

Table 3 below shows the estimation results of Model (1). We find that public employees are associated with higher wages than their observably comparable private counterparts. The sectoral gap in the year 2000 is $21 \log$ points (19 per cent), $12 \log$ points (11 per cent) in 2007, and $22 \log$ points (19 per cent) in 2014).

The adjusted wage gaps are consistently in favour of public employees, and this finding holds true for either gender and for every year. For both genders, it seems that the year 2007 was when the wage gap was lowest between the two sectors, falling to $0.8 \log$ points for men. By 2014, the wage gap increased again to more than $15 \log$ points for men and $31 \log$ points for women.

As confirmed in Table 4, the pay gap estimations at the individual level analysis is apparently consistent with the income gap estimations at the household level. Holding all other factors constant, we find that substituting a private employee for a public employee is associated with statistically significant higher household income, and this holds true for all three periods under review. That being said, the gap has somewhat lessened. This may be due to the slightly different model specification, but may also indicate either that households with no public employee may have systematically higher levels of income from sources other than the primary jobs of public and private employees. At the very least, the results in Table 4 show the same sign as the results in Table 3.

\subsection{Household consumption regression results: First indications of unreported income}

Now that we have seen that public- and private-sector income differences are consistent at both the individual and household levels, we can now move on to the main part of this study: demonstrating that there are indications of unreported income among public-sector employees. A look at Figures 1(a), 1(b), and 1(c) below will be instructive for our discussion. In the year 2000 there did not seem to be a significant difference in the consumption

Table 3. Adjusted individual public-private wage gaps, by year.

\begin{tabular}{llll}
\hline Last month's wage $(\log )$ & 2000 & 2007 & 2014 \\
\hline Sector & $-0.213^{* * *}$ & $-0.142^{* * *}$ & $-0.232^{* * *}$ \\
& $(0.0386)$ & $(0.0354)$ & $(0.0394)$ \\
Observations & 2,186 & 3,111 & 3,712 \\
R-squared & 0.342 & 0.319 & 0.268 \\
\hline
\end{tabular}

Note: Robust standard errors in parentheses. ${ }^{*} * \mathrm{p} p<0.01,{ }^{*} \mathrm{p}<0.05,{ }^{*} \mathrm{p}<0.1$. Not shown above are controls for education, experience, tenure, gender, provinces, and regional location.

Table 4. Household level income gap, yearly and panel estimates.

\begin{tabular}{lllll}
\hline Total monthly income & 2000 & 2007 & 2014 & PLS \\
\hline Private Sector & $-0.136^{* * *}$ & $-0.112^{* * *}$ & $-0.159 * * *$ & $-0.138^{* * *}$ \\
& $(0.0386)$ & $(0.0352)$ & $(0.0431)$ & $(0.0224)$ \\
Observations & 1,115 & 1,886 & 1,899 & 4,900 \\
R-squared & 0.422 & 0.349 & 0.270 & 0.496 \\
\hline
\end{tabular}

Note: Robust standard errors in parentheses. ${ }^{* * *} \mathrm{p}<0.01,{ }^{* *} \mathrm{p}<0.05,{ }^{*} \mathrm{p}<0.1$. The dependent variable uses total income constructed from the value of last month's wages or profits received from primary and secondary jobs. Not shown above are controls for number of income earners, number of other sector workers, provincial location, experience, squared experience, tenure, squared tenure, and regional location. 


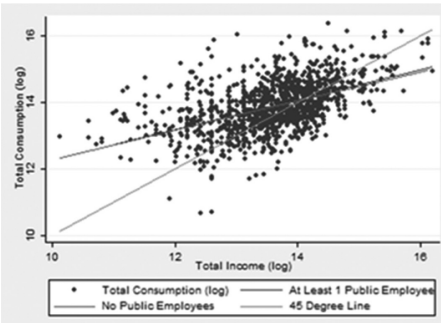

11a) Year 2000

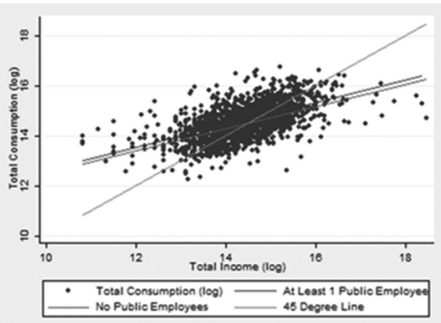

1(b) Year 2007

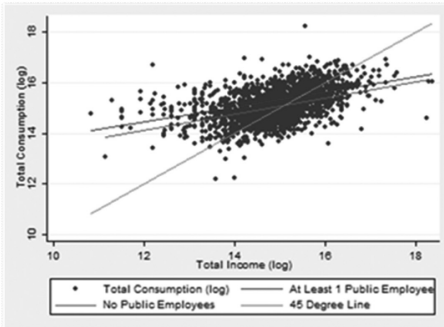

1 (c) Year 2014

Figure 1. Consumption to income linear fits by household type. Years 2000, 2007, and 2014. Note: Consumption is here defined as total market-based expenditures, and income is constructed using last month's wages or profits from primary and secondary jobs and all non-labour income.

to income levels of households with no public employees and households with at least one public employee. This means that given the same income, there is no apparent difference in the consumption levels of both types of household. Yet, a gap clearly exists if we compare the consumption to income profile of the year 2007 in Figure 1(b) with that of year 2000 in Figure 1(a), and an even larger gap when we see the profile of year 2014 in Figure 1(c). This indicates that there has apparently been a behavioural evolution within at least one of the two types of households: generally speaking, households with at least one public employee seem to increasingly be consuming more of their reported income compared to households without public employees, even though the differences in their reported income has stayed roughly constant over the three periods.

The finding can also be summarised in Figure 2. During the year 2000, households with no public employees have higher mean and median levels of APC (Average Propensity to Consume; in logarithm) than households with at least one public employee, as is expected of a group with lower incomes. However, theoretically, what we would expect to find is for APC to grow smaller as incomes rise, because as people get richer (in income terms) they will spend a smaller proportion of their income on consumption. This theoretical proposition holds true for households with no public employees. Nevertheless, households with at least one public employee seem to have rising APC values over the course of three years. These figures are in themselves quite suspicious, as those show that households with at least one public employee have systematically different behaviours compared to our control group.

The pattern of increasingly larger consumption differences between sectors is confirmed in Table 5. In the year 2000, there did not seem to be a statistically significant difference between the consumption levels within a comparable household were we to substitute a public employee for a private employee. However, by the year 2007, a difference of $0.05 \mathrm{log}$ points ( 4 per cent) was detected in consumption were we to substitute a private employee for a public employee, and by the year 2014, an even stronger difference in consumption was detected. This is our first indication that public-sector employees receive income above what they have actually reported. In the year 2014, even after controlling household and income 


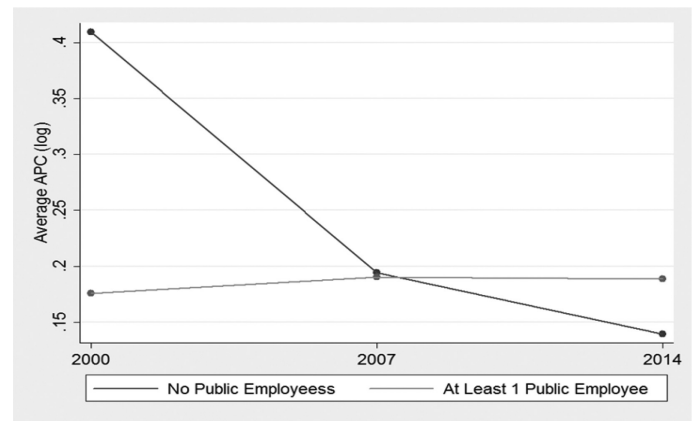

Figure 2. Mean APC by household type and year.

Table 5. Household total consumption difference, by year.

\begin{tabular}{llll}
\hline Total consumption & 2000 & 2007 & 2014 \\
\hline Private Sector & 0.00933 & $-0.0537^{* *}$ & $-0.152^{* * *}$ \\
& $(0.0351)$ & $(0.0251)$ & $(0.0274)$ \\
Observations & 1,173 & 1,941 & 2,006 \\
R-squared & 0.364 & 0.443 & 0.372 \\
\hline
\end{tabular}

Note: Robust standard errors in parentheses. $* * * p<0.01, * * p<0.05,{ }^{*} \mathrm{p}<0.1$. Not shown above are controls for number of income earners, number of other sector workers, total income, provincial location, household size, regional location, average years of schooling of employees, the proportion of men between employees, average age of household members, and average age of employees.

earner characteristics, including the level of total household income, substituting a publicsector employee with a private-sector employee was associated with a $0.15 \log$ points (14 per cent) difference in total consumption.

What this author has further decided to do is to divide the sample into five groups according to the income of the household's head (defined as the person with the largest income within a household) in each year, resulting in 15 different groups. Upon each group, we will use empirical Model (3) to estimate differences in consumption levels for each income group. The results as seen in Table 6 are more nuanced. A majority of the results show that substituting a private employee for a public employee is associated with smaller consumption levels, with all other factors including income held as constant. Nonetheless, some income groups show the opposite sign, and this means that rather than among public employees, there are actually indications of unreported income among private employees. That being said, most of the results show that having a public employee in a household instead of a private employee is associated with higher consumption levels, ceteris paribus, and this finding is strongest in the year 2014 .

\subsection{The probability of reporting consumption higher than income: Results}

However, look back again at Figures 1 and 2 which show that there is still a lack of components in our analysis. Theoretically, we would expect to see a value of APC between zero and one, meaning that consumption does not surpass income. In logarithmic terms, this would mean that the normal values of the $\log$ of APC are negative. Nevertheless, Figure 2 shows that the average $\log$ of APC is above 1. Even if we were to allow for the fact that some households might be in debt, it seems unlikely that the number of indebted 
Table 6. Total consumption differences, by year and quintile of income.

\begin{tabular}{lllllll}
\hline Year & & 1st Quintile & 2nd Quintile & 3rd Quintile & 4th Quintile & 5th Quintile \\
\hline 2000 & Private Sector & $-0.232^{*}$ & $-0.155^{*}$ & $0.165^{* *}$ & -0.0604 & -0.0596 \\
& & $(0.130)$ & $(0.0833)$ & $(0.0786)$ & $(0.0754)$ & $(0.0565)$ \\
& Observations & 283 & 232 & 193 & 232 & 233 \\
2007 & R-squared & 0.268 & 0.214 & 0.249 & 0.135 & 0.300 \\
& Private Sector & $-0.175^{* *}$ & -0.0397 & -0.0673 & -0.0783 & $-0.128^{* * *}$ \\
& & $(0.0699)$ & $(0.0635)$ & $(0.0507)$ & $(0.0490)$ & $(0.0458)$ \\
& Observations & 402 & 412 & 401 & 348 & 379 \\
2014 & R-squared & 0.177 & 0.234 & 0.252 & 0.244 & 0.205 \\
& Private Sector & $-0.175^{* *}$ & -0.0397 & -0.0673 & -0.0783 & $-0.128^{* * *}$ \\
& & $(0.0699)$ & $(0.0635)$ & $(0.0507)$ & $(0.0490)$ & $(0.0458)$ \\
& Observations & 402 & 412 & 401 & 348 & 379 \\
& R-squared & 0.177 & 0.234 & 0.252 & 0.244 & 0.205 \\
\hline
\end{tabular}

Note: Robust standard errors in parentheses. ${ }^{* * *} \mathrm{p}<0.01,{ }^{* *} \mathrm{p}<0.05,{ }^{*} \mathrm{p}<0.1$.

Not shown above are controls for total household income, number of income earners, number of other sector workers, household size, years of schooling, the proportion of men among sector employees, proportion of married people among sector employees, provinces, region, average household age, and average age of sector employees.

households and the magnitude of their debt is as large as Figure 2 suggests. There are only two explanations for this. The first one is that consumption has been over-reported. To a certain extent this may be due to imperfections in survey collection: respondents may have - for whatever reason - upwardly biased the quantity or price of the goods and services they have consumed. The other is that income has been under-reported, which is exactly what this study hopes to prove.

The next step in our study is to see whether or not it is more likely for households with at least one public employee to report expenditures larger than their income compared to households without a public employee. Figures 3(a), 3(b), and 3(c) are a good starting place to see this point. In those figures, the author has divided households into five groups according to the income of the household head, with Q1 having the lowest income and Q5 the highest, and further dividing them into households without a public employee (0 PE) and with at least one public employee ( $>0 \mathrm{PE}$ ). With the few exceptions being some income groups in the year 2000, the group of households with at least one public employee always had higher proportions of households that report their consumption above their incomes than households with no public employees.

The LPM regression results presented in Table 7 further confirm the pattern of behavioural change discussed in the preceding sub-chapter. In the year 2000, there did not seem to be a statistically significant difference in the likelihood a household reports expenditures above income when we substitute a private employee for a public employee. Yet, by the year 2014, substituting a private for a public employee appeared to significantly decrease that probability across the income distribution.

\subsection{Analysis and discussion}

The results of this study suggest that public employees surveyed in the IFLS consume more than a private employee given the same income, providing a somewhat weak indication that there was unreported income among public employees, at least in the years 2007 and 2014. The results of study where we find that government employees consume more of their income can still be explained without invoking corruption or even unreported income. Government employees in Indonesia receive greater fringe benefits, higher employment security, and they may even have inherently different behavioural attitudes towards risks compared to their private-sector counterparts. All of this serves as a potential explanation why government employees are more consumptive than private employees. 


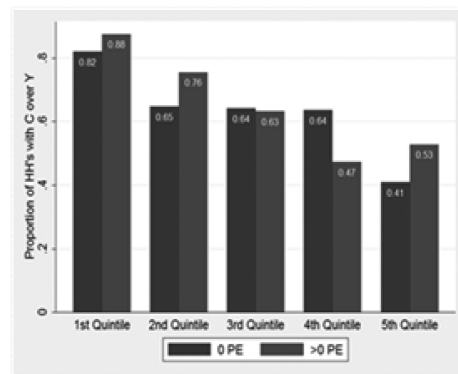

$3($ a) Year 2000

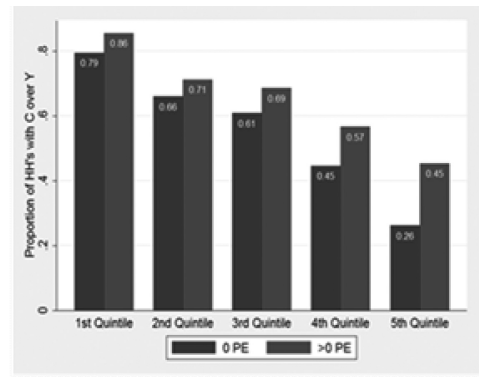

3 (b) Year 2007

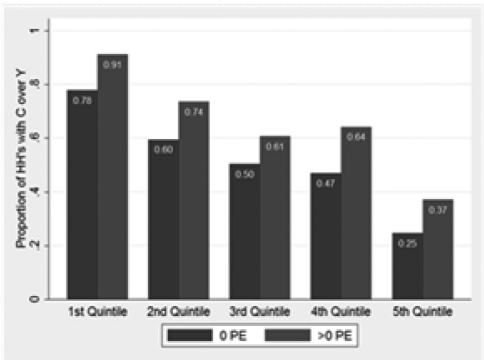

$3(c)$ Year 2014

Figure 3. Proportion of households with expenditures above income, by income quintiles of household head and household type. Years 2000, 2007, and 2014.

Table 7. Probability of reporting consumption over income by year and quintile of income.

\begin{tabular}{lllllll}
\hline Year & & 1st Quintile & 2nd Quintile & 3rd Quintile & 4th Quintile & 5th Quintile \\
\hline 2000 & Private Sector & -0.0757 & -0.0197 & $0.154^{* *}$ & $0.161^{* * *}$ & -0.0431 \\
& & $(0.0608)$ & $(0.0615)$ & $(0.0607)$ & $(0.0577)$ & $(0.0493)$ \\
& Observations & 286 & 233 & 194 & 232 & 235 \\
2007 & R-squared & 0.187 & 0.194 & 0.149 & 0.088 & 0.092 \\
& Private Sector & -0.0320 & -0.0244 & -0.0182 & -0.0562 & $-0.0996^{* *}$ \\
& & $(0.0441)$ & $(0.0519)$ & $(0.0469)$ & $(0.0444)$ & $(0.0399)$ \\
& Observations & 404 & 413 & 405 & 350 & 380 \\
& R-squared & 0.165 & 0.183 & 0.115 & 0.066 & 0.091 \\
& Private Sector & 0.00600 & -0.00699 & $-0.159 * * *$ & $-0.0904 *$ & $-0.0912^{* *}$ \\
& & $(0.0316)$ & $(0.0696)$ & $(0.0578)$ & $(0.0474)$ & $(0.0417)$ \\
& Observations & 406 & 417 & 388 & 410 & 394 \\
& R-squared & 0.203 & 0.229 & 0.215 & 0.174 & 0.155 \\
\hline
\end{tabular}

Note: Robust standard errors in parentheses. ${ }^{* * *} \mathrm{p}<0.01,{ }^{*} \mathrm{p}<0.05,{ }^{*} \mathrm{p}<0.1$.

Not shown above are controls for total household income, number of income earners, number of other sector workers, household size, years of schooling, the proportion of men among sector employees, proportion of married people among sector employees, provinces, region, average household age, and average age of sector employees.

However, the fact that households with public employees are clearly more prone to reporting expenditures above their reported income compared to households without them does strengthen the case of public employees under-reporting their true income. The finding that substituting a public employee for a private employee is strongly associated with a higher probability that a household reporting expenditures above income cannot be taken trivially. 
Particularly in the highest quintiles of income, the argument of public employees having higher employment security, greater fringe benefits, nor inherently different attitudes towards risks is unable to explain that finding.

All this being said, there are many weaknesses of this paper stemming either from the limitations of the available data or the author. Concerning the data, the author was not able to distinguish between employees of state-owned enterprises (national or regional), civil servants, or elected public officials. Although the IFLS data allows us to distinguish between different types of occupations (blue-collar, administrative, and professional/technical), yet the resulting size of the sub-samples (particularly for the white-collar jobs) the author judges to be insufficient as a basis for a meaningful statistical analysis. This is also the reason why the author decided not to do the same analysis for each provincial region, even though the differences in income levels and standards of living between provinces would undoubtedly have an effect on the consumption behaviour of public employees.

The diminutiveness of the data is also the reason why this paper did not distinguish the time when the subjects were surveyed. The timing of observations is of importance because it is very common for employees (whether public or private) to receive more than 12 times their salaries per year, as there are various bonuses that a person may receive during different times of the year. Most Indonesians usually receive an extra salary after the fasting season each year, while many organisations (whether state-owned enterprises or private firms) also disburse bonuses to their employees at the end of the year. These weaknesses thus mean that extreme caution must be taken in interpreting the results hitherto presented.

\section{CONCLUSION}

Although the individual wage or household income differences between public and private employees stayed roughly constant between the years 2000 to 2014, we have found that public employees increasingly consume more compared to private employees given the same levels of income. This serves as our first indication that Indonesian public employees may have received income other than what was reported by the IFLS. To a certain extent, this behavioural difference may be explained by the fact that public employees receive greater fringe benefits or higher employment security, which may affect their attitudes towards risks and thus their consumption behaviour.

A stronger indication of unreported income that we have found is that public employees are more prone to reporting expenditure levels above their income than private employees, a fact that has grown stronger over time and more pronounced as we get higher up the income distribution. The finding that public employees have a higher probability of reporting expenditures levels higher than income cannot be explained by the fact that public employees have higher employment security or greater fringe benefits, and thus this serves as this study's second and stronger indication that public employees receive higher incomes than what they have reported.

\section{REFERENCES}

Antón, J.I., and de Bustillo, R.M., 2015. Public-private sector wage differentials in Spain. An updated picture in the midst of the Great Recession. Investigación económica, 74(292), pp.115-157.

Azam, M., \& Prakash, N. (2015). A Distributional Analysis of the Public-Private Wage Differential in India. Labour, 29(4), 394-414.

Bargain, O., \& Melly, B. (2008). Public Sector Pay Gap in France: New Evidence Using Panel Data.

Borjas, G. (2002). The Wage Structure and the Sorting of Workers into the Public Sector. National Bureau of Economic Research.

Christofides, L.N. \& Michael, M. (2013). Exploring the public-private sector wage gap in European countries. IZA Journal of European Labor Studies, 2(1), 1-53. doi:10.1186/2193-9012-2-15.

Dur, R. \& Zoutenbier, R. (2015). Intrinsic motivations of public sector employees: Evidence for Germany. German Economic Review, 16(3), 343-366. doi:10.1111/geer.12056. 
Fisman, R. \& Gatti, R. (2002). Decentralization and corruption: Evidences across countries. Journal of Public Economics, 83(3), 325-345. doi:10.1016/S0047-2727(00)00158-4.

Gorodnichenko, Y., Martinez-Vazquez, J. \& Peter, K.S. (2009). Myth and reality of flat tax reform: Micro estimates of tax evasion response and welfare effects in Russia. Journal of Political Economy, 117(3), 504-554. doi:10.1086/599760.

Gorodnichenko, Y. \& Peter, K.S. (2007). Public sector pay and corruption: Measuring bribery from micro data. Journal of Public Economics, 91(5-6), 963-991. doi:10.1016/j.jpubeco.2006.12.003.

Gourinchas, P.O. \& Parker, J.A. (2002). Consumption over the life cycle. Econometrica, 70(1), 47-89. doi:10.1111/1468-0262.00269.

Haider, S. \& Solon, G. (2006). Life-Cycle variation in the association between current and lifetime earnings. American Economic Review, 96(4), 1308-1320. doi:10.1257/aer.96.4.1308.

Hurst, E., Li, G. \& Pugsley, B. (2014). Are household surveys like tax forms? Evidence from income underreporting of the self-employed. The Review of Economics and Statistics, 96(1), 19-33. doi:10.3386/w16527.

Hyder, A., \& Reilly, B. (2005). The Public and Private Sector Pay Gap in Pakistan: A Quantile Regression Analysis. The Pakistan Development Review, 271-306.

Mueller, R.E. (1998). Public-Private sector wage differentials in Canada: Evidence from quantile regressions. Economics Letters, 60(2), 229-235. doi:10.1016/S0165-1765(98)00110-4.

Nielsen, H.S., \& Rosholm, M. (2002). The Public-Private Sector Wage Gap in Zambia in the 1990's: A Quantile Regression Approach. Economic Applications of Quantile Regressions, 169-182.

Pissarides, C.A. \& Weber, G. (1989). An expenditure-based estimate of Britain's black economy. Journal of Public Economics, 39(1), 17-32. doi:10.1016/0047-2727(89)90052-2.

Saha, S., Roy, P. \& Kar, S. (2014). Public and private sector jobs, unreported income and consumption gap in India: Evidence from micro-data. North American Journal of Economics and Finance, 29, 285-300. doi:10.1016/j.najef.2014.07.002.

Strauss, J., Witoelar, F. \& Sikoki, B. The fifth wave of the Indonesia family life survey (IFLS5): Overview and field report. March 2016. WR-1143/1-NIA/NICHD.

Strauss, J., Witoelar, F., Sikoki, B. \& Wattie, A.M. The fourth wave of the Indonesian family life survey (IFLS4): Overview and field report. April 2009. WR-675/1-NIA/NICHD.

Strauss, J., Beegle, K., Sikoki, B., Dwiyanto, A., Herawati, Y. \& Witoelar, F. The third wave of the Indonesia family life survey (IFLS): Overview and field report, March 2004. WR-144/1-NIA/NICHD. 